\title{
Teachers' Perceptions about Using Songs in Vocabulary Instruction to Young Language Learners
}

\author{
Tien Cam Nguyen ${ }^{1}$, Huan Buu Nguyen,"* \\ ${ }^{1}$ Aston English Language Center, Vietnam \\ ${ }^{2}$ School of Foreign Languages, Can Tho University, Vietnam
}

Received March 12, 2020, Revised April 20, 2020; Accepted May 3, 2020

Copyright $(2020$ by authors, all rights reserved. Authors agree that this article remains permanently open access under the terms of the Creative Commons Attribution License 4.0 International License

\begin{abstract}
There is an increasingly pressing demand for improving the quality of teaching and learning English in Vietnam to meet the needs and interests of learners in the global integration. Research into vocabulary instruction through songs has indicated its positive effects on young learners' vocabulary gains and language learning, including English as a foreign or second language. However, little research focuses on the use of songs perceived by teachers in vocabulary instruction to young learners within the teaching and context in Vietnam where English is taught as a foreign language. This paper therefore considers teachers' perceptions about this instructional delivery at a foreign language center in the Mekong Delta. A descriptive study was conducted with seventy-five teachers from an English language center in the Mekong Delta. Data on teachers' perceptions about using songs to teach young learners' vocabulary were collected through the questionnaire and follow-up semi-structured interviews as part of a wider study over fifteen-week semester time. The findings indicate that teachers had positive perceptions about songs used in vocabulary instruction for young learners. Also, the findings provide teachers with insightful views of the effectiveness of implementing songs in promoting young learners' vocabulary and serve as a useful resource for teachers and practitioners by suggesting how to use songs to facilitate young learners' vocabulary. The paper concludes by giving pedagogical implications for further research into seeking alternative ways to maximize young learners' vocabulary learning.
\end{abstract}

Keywords Songs, Vocabulary Instruction, Young Learners, Perceptions

\section{Introduction}

Vocabulary is widely held as an indispensable part in helping learners become competent in foreign or second language learning [1-3]. Songs are viewed as one of the most effective ways for vocabulary learning [4-6]. According to Pavia and colleagues[6], songs are known as valuable resource for vocabulary learning as they provide learners with an opportunity to gain a large amount of words, allow for repetition, learn both individual and sequence of words, retain memory, reduce anxiety, and foster acquisition. Recent reforms in Vietnam have stressed the quality of foreign language teaching and learning across all school levels, particularly English to meet the learners' needs and interests to work or study in the globalized era [7]. This calls for change sets high expectations for teachers to seek ways or strategies to enhance learners' English language proficiency. Vocabulary learning provides learners with an opportunity to use that language and communicate with others [8-10]. One way to help learners to achieve this goal is learning vocabulary through songs. Research into the use of songs in language teaching has indicated its effects on improving vocabulary acquisition and motivation in young learners $[11,12]$. However, evidence shows that the benefits of songs for vocabulary gains have received little attention from empirical studies [13] and yielded less strong findings [14]. In Vietnam, this type of instruction is limited within the context of teaching and learning English and teachers' perceptions about songs in young learner class are needed. This paper, therefore, attempts to investigate this aspect of learning. 


\section{The Literature}

The following section reviews the literature on perceptions, young learners and vocabulary learning, songs and vocabulary instruction.

\subsection{Perceptions}

There are several definitions of perceptions in the literature. Perceptions are defined as an individual's ability to think and understand information or the world around us through senses [e.g., 15, 16, 17]. Perceptions are viewed as an experience-based process of information [16] or a process of recognizing, organizing, and interpreting information [15]. These views imply that teachers' perceptions are key to the teaching and learning process. In particular, teachers must perceive that their instructions are accountable for learners to approach or acquire foreign languages, particularly English [18]. For the purposes of this study reported in this paper, the term 'perceptions' refers to teachers' understanding or awareness of doing things that enhance learners' knowledge.

\subsection{Perceptions about Vocabulary Instruction}

Studies have shown that teachers perceived vocabulary instruction as an essential part of language teaching and learning, especially in learning a foreign language $[3,9]$. Two approaches to vocabulary instruction include explicit and incidental learning [1]. While the former is targeted at word study, the latter involves focusing more on the use of language than the learning itself. As depicted as incidental, vocabulary instruction denotes words learned through exposures in the contexts and experiences $[19,20]$ or in other words, it is viewed as a by-product of reading and listening in and outside the classroom milieu[21]. Thus, this practice influences vocabulary learning of learners. This type of instruction also enables learners to develop four language skills of reading, writing, speaking, and listening for meaning-focused, fluency, and language-focused features [22-24]. Meaning-focused instruction involves key ideas from particular messages generated by the learners to others. Fluency entails practices that learners are likely to become fluent and capable of using the target language. Language-focused vocabulary knowledge takes place when other aspects of language, such as grammar, writing, and syntax to name a few, are provided during instruction [24]. From these perspectives, this study provides insights into the potentiality of the use of vocabulary strategies to promote young learners' vocabulary gains.

\subsection{Young Learners and Vocabulary Learning}

There are several ways to define the term 'young learners' in the literature. The term 'young learners' generally understood as any learner under the age of eighteen can be vague since it indicates a varying age range with regard to big difference in physical, emotional, social, and cognitive development among children[25]. Thus, to clarify this concept, Ellis suggests a list of terms to describe young learners according to life stage to align with early years, pre-primary and primary schooling in English language teaching profession for age range from two to five, six to ten or eleven respectively. Young learners are viewed as either first-year learners of formal schooling, or those between the ages of five or six to eleven or twelve[26] or any learners from five to twelve to learn a foreign or second language [27-29]. In this study, young learners are defined as ones from the age of five up to nine years old since kids first start very basic English classes at a foreign language center.

Young learners process information in both their native language (L1) and foreign language (L2) differently from adult learners because the former classify words related to concrete objects from an early age [30]. Young learners, who even do not quite understand why or how to do things, tend to be more active, enthusiastic, and energetic to participate in an activity than adult learners. Young learners tend to lose concentration more quickly and are less able to keep themselves interested in doing difficult tasks [31]. Young learners are interested in imagination and movement [32]. In other words, they are energetic and physically active because they cannot sit in one place for too long [33]. These views suggest that young learners' vocabulary acquisition is an active process that engages them with language contexts or patterns. As vocabulary plays a crucial part of language proficiency and communication with others $[8,34,35]$, young learners need to be provided greater exposure to lexical knowledge in effective ways.

\subsection{Songs in Vocabulary Instruction to Young Learners}

Research has indicated that songs can be a potential tool for facilitating young learners' vocabulary learning and enhancement [e.g., 4, 36, 37]. Songs, as pieces of music, benefit young learners in several ways. Songs offer a gaiety, fun and friendly atmosphere in the classroom and tendentiously attract the attention of young learners [38, 39]. According to [4], songs can impact on the receptive lexical knowledge of learners when exposed to both sung and spoken forms through a theme or topic[11, 14, 40]. Songs help teachers to provide young learners with language knowledge based on teachers' design of different activities and draw young learners' attention easily [41]. They allow learners to get a large amount of words, expose to using both individual and sequences of words through repetition and occurrences, retain words, and reduce anxiety in classrooms[6, 14]. As noted by [12], the popularity of the use of songs in foreign language classes is 
evidenced in United States [42], the United Kingdom [43], China [44], Greece [45], Japan [46], Malaysia [47], and Vietnam [48]. Furthermore, songs used in English classrooms can foster learners' interest and motivate them to learn and enhance their vocabulary gains in English [5, 49]. Despite a plethora of empirical research of the effects of songs in young learner classes, the question as to perceptions about vocabulary acquisition with songs remains scarce. This paper attempts to fill the gaps in the literature on teachers' perceptions about songs used within the Vietnamese context of teaching and learning English to enhance young learners' vocabulary growth.

\section{The Study}

This study was undertaken in a foreign language center in the Mekong Delta area over a fifteen-week semester period of academic years 2018-2019. The aim was to examine teachers' perceptions about the use of songs in vocabulary instruction to young learners.

A descriptive study using mixed- methods design was conducted to investigate teachers' perceptions about songs used in vocabulary instruction to young learners at a foreign language center. Questionnaires, classroom observations, and interviews were the three research instruments. The thirty-three questionnaire was organized into four clusters. The first cluster focuses on teachers' perceptions about the use and benefits of songs in vocabulary instruction [items 1-15]. The second cluster is targeted at teachers' views of challenges of using songs while teaching vocabulary [items 16-20]. The third cluster sough to explore teachers' ways of selecting songs in vocabulary instruction [items 21-27]. The fourth cluster is centered on teachers' implementation of songs to teach young learners' vocabulary. There are two open-ended questions at the end of the questionnaire for obtaining further ideas or views from teachers. Classroom observations were the second tool for recording the happenings or occurrences of teachers' implementation of songs in their classes. At the end of the study, semi-structured interviews were conducted with teachers to obtain their views of the four above-mentioned aspects in the questionnaire. However, for the purposes of this paper, the data discussed are mainly drawn from the questionnaires and interviews with the teachers. Pseudonyms were used to protect teachers' identities.

Participants in this study were seventy-five teachers at a foreign language center in the Mekong Delta, Vietnam. At the time of the study, the range of the participants' teaching experience was from one to five years. The teachers' participation was voluntary when they were asked to respond to the questionnaire. Of the total population, nine teachers were selected to participate in the semi-structured interviews to gain insights into their views of songs to teach young learners vocabulary. Each interview took approximately half an hour.

The quantitative data from the questionnaire were statistically analyzed using an SPSS (Statistical Package for the Social Sciences). The questionnaire is weighted by the rubric of five-point Likert scale (1=strongly disagree; $2=$ disagree; $3=$ neutral/ undecided; $4=$ =agree; and $5=$ =strongly agree). The pilot study was delivered to forty-two teachers who were working in other language centers to check the reliability of the items in the questionnaire. The Cronbach's alpha for this pilot .791 indicates the high reliability of the questionnaire for collecting the data for this study. All interview responses were recorded, transcribed, and translated from Vietnamese to English. The data were analyzed by thematic analysis.

\section{Findings}

\subsection{Findings from Questionnaires}

This section presents the findings of the study with regard to teachers' perceptions about the use and benefits of songs in vocabulary instruction in EFL young learners classrooms. The findings reveal teachers' positive perceptions about this area of study.

\subsection{Insights into Teachers' Perceptions about Songs in Vocabulary Instruction}

Section One of the questionnaire contains nine items with regard to teachers' perceptions about songs in vocabulary instruction to young learners (VIYLs), as shown in Table 1.

Table 1 shows that teachers' perceptions about songs in vocabulary instruction to young learners are at high level. Of the total of 75 surveyed teachers responded to the questionnaire, 74 teachers (98.6\%), the highest response rate, indicated that songs are effective in teaching vocabulary to young learners (item 2), followed by 71 teachers (94.7\%) who believed that songs are essential and draw learners' attention to the lesson (items $1 \& 4$ ). When asked if songs are important to develop young learners' vocabulary (item 3), 69 teachers (92\%) indicated the high level of agreement on the role of songs. Songs are also reported as providing young learners with opportunities to practice (85.3\%), learn English (84\%), and identify word meanings in context (82.6\%), and maintain frequent practice $(80 \%)$. These results show the high level of agreement or consensus among teachers about the effectiveness of songs to improve young learners' vocabulary achievement or performance.

\subsection{Teachers' Perceptions about Benefits of Songs in VIYLS}

Section Two of the questionnaire consists of six items 
with regard to teachers' perceptions about benefits of songs when teaching vocabulary to young learners, as indicated in Table 2.

Table 2 shows the frequency and percentage distribution of teachers' perceptions about benefits of songs in vocabulary instruction to young learners (VIYLs). The majority of responses falls between the category of 'Neutral and Agree'. In particular, Item 10 represents $98.7 \%(n=74)$, the highest response rate, of the participants who recognized that songs are used to facilitate young learners' vocabulary retention. The second response rate came with Item 15 as $94.7 \%(n=71)$ of the participants perceived that songs provide young learners with opportunities for vocabulary revision. The third response rate goes with Item 14 indicating that $73.3 \%(n=55)$ of the participants considered songs help learners improve their vocabulary input, followed by $68 \%(n=51)$ of responses to Item 13 regarding songs that draw learners' attention to vocabulary. Moreover, about two-thirds of the participants (69.3\% and 61.3\%, respectively) agreed that songs are good tools for learners to pick up and practice vocabulary as well as expand their words.

Table 1. Teachers' perceptions about songs in vocabulary instruction

\begin{tabular}{|c|c|c|c|c|c|c|c|}
\hline & \multicolumn{7}{|l|}{ Frequencies } \\
\hline & \multirow[b]{2}{*}{ Item } & \multicolumn{2}{|c|}{$\begin{array}{c}\text { Disagree\& } \\
\text { strongly disagree }\end{array}$} & \multicolumn{2}{|c|}{ neutral } & \multicolumn{2}{|c|}{$\begin{array}{c}\text { Agree\& } \\
\text { Strongly agree } \\
\end{array}$} \\
\hline & & $\mathbf{n}$ & $\%$ & n & $\%$ & $\mathbf{n}$ & $\%$ \\
\hline 1 & $\begin{array}{l}\text { I think it is necessary to use songs to teach vocabulary to young } \\
\text { learners. }\end{array}$ & 2 & 2.6 & 2 & 2.7 & 71 & 94.7 \\
\hline 2 & I think it is effective to use songs to teach vocabulary to young learners. & 0 & 0 & 1 & 1.3 & 74 & 98.6 \\
\hline 3 & I think songs are important in developing young learners' vocabulary. & 0 & 0 & 6 & 8.0 & 69 & 92 \\
\hline 4 & I think songs can draw young learners' attention to the lesson. & 0 & 0 & 4 & 5.3 & 71 & 94.7 \\
\hline 5 & $\begin{array}{l}\text { I think songs provide young learners with opportunities to learn } \\
\text { English. }\end{array}$ & 2 & 2.7 & 10 & 13.3 & 63 & 84 \\
\hline 6 & $\begin{array}{l}\text { I think songs provide young learners with opportunities to practice } \\
\text { vocabulary. }\end{array}$ & 1 & 1.3 & 10 & 13.3 & 64 & 85.3 \\
\hline 7 & I think songs allow learners to practice vocabulary regularly. & 2 & 2.7 & 13 & 17.3 & 60 & 80 \\
\hline 8 & $\begin{array}{l}\text { I think songs used to teach vocabulary can offer young learners a } \\
\text { friendly environment. }\end{array}$ & 1 & 1.3 & 7 & 9.3 & 67 & 89.3 \\
\hline 9 & $\begin{array}{l}\text { I think songs create a meaningful context for young learners to gain } \\
\text { vocabulary. }\end{array}$ & 2 & 2.7 & 11 & 14.7 & 62 & 82.6 \\
\hline
\end{tabular}

Table 2. Teachers' perceptions about benefits of songs in VIYLs

\begin{tabular}{|c|c|c|c|c|c|c|c|}
\hline & \multicolumn{7}{|l|}{ Frequencies } \\
\hline & \multirow[b]{2}{*}{ Item } & \multicolumn{2}{|c|}{$\begin{array}{c}\text { Disagree \& } \\
\text { strongly disagree }\end{array}$} & \multicolumn{2}{|c|}{ Neutral } & \multicolumn{2}{|c|}{$\begin{array}{c}\text { Agree \& } \\
\text { strongly agree }\end{array}$} \\
\hline & & $\mathbf{n}$ & $\%$ & n & $\%$ & $\mathbf{n}$ & $\%$ \\
\hline 1 & I think songs facilitate young learners' vocabulary retention. & 0 & 0 & 1 & 1.3 & 74 & 98.7 \\
\hline 2 & $\begin{array}{l}\text { I think songs allow young learners to learn more vocabulary than } \\
\text { usual. }\end{array}$ & 1 & 1.3 & 28 & 37.3 & 46 & 61.3 \\
\hline 3 & $\begin{array}{l}\text { I think songs can create conditions for young learners to learn and } \\
\text { practice vocabulary. }\end{array}$ & 4 & 5.3 & 19 & 25.3 & 52 & 69.3 \\
\hline 4 & I think songs can help young learners focus on vocabulary. & 7 & 9.3 & 17 & 22.7 & 51 & 68 \\
\hline 5 & I think songs can help young learners develop vocabulary. & 4 & 5.3 & 16 & 21.3 & 55 & 73.3 \\
\hline 6 & $\begin{array}{l}\text { I think songs can offer young learners opportunities to review } \\
\text { vocabulary. }\end{array}$ & 1 & 1.3 & 3 & 4.0 & 71 & 94.7 \\
\hline
\end{tabular}


Table 3. Teachers' perceptions about the use of songs in VIYLs

\begin{tabular}{|c|c|c|c|c|c|c|c|}
\hline & \multicolumn{7}{|c|}{ Frequencies } \\
\hline & \multirow[b]{2}{*}{ Item } & \multicolumn{2}{|c|}{$\begin{array}{c}\text { Disagree \& } \\
\text { strongly disagree }\end{array}$} & \multicolumn{2}{|c|}{ Neutral } & \multicolumn{2}{|c|}{$\begin{array}{c}\text { Agree \& } \\
\text { strongly agree }\end{array}$} \\
\hline & & n & $\%$ & $\mathbf{n}$ & $\%$ & $\mathbf{n}$ & $\%$ \\
\hline 1 & $\begin{array}{l}\text { The teacher sets the context before using songs } \\
\text { to teach vocabulary to young learners. }\end{array}$ & 2 & 2.7 & 5 & 6.7 & 68 & 90.7 \\
\hline 2 & $\begin{array}{l}\text { The teacher introduces new vocabulary before having learners } \\
\text { listen to a song. }\end{array}$ & 4 & 5.3 & 7 & 9.3 & 64 & 85.4 \\
\hline 3 & $\begin{array}{l}\text { The teacher encourages young learners to act out or mime words in } \\
\text { the song. }\end{array}$ & 3 & 4 & 12 & 16 & 60 & 80 \\
\hline 4 & $\begin{array}{l}\text { The teacher plays the song multiple times for young learners to } \\
\text { repeat words. }\end{array}$ & 2 & 2.7 & 3 & 4 & 70 & 93.4 \\
\hline 5 & $\begin{array}{l}\text { The teacher delivers handouts of a song and asks young learners to } \\
\text { fill the gaps and match words using pictures with lines. }\end{array}$ & 8 & 10.6 & 7 & 9.3 & 60 & 80 \\
\hline 6 & $\begin{array}{l}\text { The teacher plays the song again to check learners' understanding } \\
\text { and memory of words. }\end{array}$ & 1 & 1.3 & 6 & 8 & 68 & 90.7 \\
\hline
\end{tabular}

\subsection{Teachers' Perceptions about the Use of Songs in VIYLS}

Findings from six items about teachers' perceptions about the use of songs in vocabulary instruction are shown in Table 3.

As can be seen in Table 3, the frequency and percentage distribution of each item (Items 16 to 21) regarding teachers' perceptions about the use of songs in VIYLs, whereby the majority of responses fall between the category of 'Agree and Strongly Agree' (high level of agreement). In particular, Item 19 represents the highest response rate of $93.4 \%(n=70)$ of the participants who have learners listen to the song several times in order to repeat words. Items 16 and 21 ranked second as $90.7 \%(n=68)$ of the participants set the context before playing the song and replay a song to check if learners understood and remembered the words in that song. $85.4 \%(n=64)$ of participants' responses to Item 17 indicating that the teacher introduced new vocabulary before having learners listen to the song. $80 \%$ of the participants responded that they encouraged learners to act out or mime words as well as practice gap-fill or matching exercises.

\subsection{Findings from the Interviews}

Teachers' perceptions about using songs in vocabulary instruction to young learners

The findings indicate that nine interviewed teachers reported positive perceptions about using songs in vocabulary instruction to young learners. The six themes are identified as memorizing vocabulary, reviewing vocabulary, drawing attention, stimulating learning atmosphere, improving reading and writing of words, and facilitating pronunciation.

\subsection{Memorizing Vocabulary}

Three of nine teachers claimed that songs contributed to young learners' memorizing words. The following extracts illustrate their views.

"Songs can help young learners to expand their vocabulary and memorize words more deeply when they listen to songs and sing them again”. (Huong, interview extract).

"Songs containing contexts make young learners remember vocabulary very easily." (Nhi, interview extract).

"Songs provide young learners with opportunities to expand vocabulary by looking at other words and asking for meanings" (Lan, interview extract).

\subsection{Reviewing Vocabulary}

Two teachers reported that listening to songs could help learners review words. Chi emphasized that pictures and actions in video songs facilitated young learners' vocabulary development and vocabulary revision. Chi said,

"When listening to video songs with following pictures and doing actions in songs, young learners will review vocabulary from previous lessons." (Chi, interview extract).

Ngoan indicated that songs helped to review vocabulary for young learners thanks to the song actions and melodies. She shared,

"Songs help learners review vocabulary because they remember the song and automatically sing it when listening and acting it out." (Ngoan, interview extract).

\subsection{Drawing Learners' Attention}

Two teachers asserted that young learners could concentrate more on vocabulary learning when they 
listened to songs. Khai asserted that the teacher could draw young learners' attention to the lesson when playing the songs. Khai said,

"Young learners will concentrate more on the lesson because the teacher plays the song to engage students in listening." (Khai, interview extract).

In Ngoan's views, melodies of songs made young learners attentive in learning vocabulary. Ngoan said,

"Songs attract their attention to the vocabulary learning because the young learners like listening to melodies in the songs." (Ngoan. interview extract).

\subsection{Providing Stimulating Learning Environment}

Three teachers believed that songs helped young learners to avoid boredom and distraction in vocabulary learning. The following extracts illustrate their views.

"Listening to songs, young learners will not feel bored and are easy to do whatever the teacher asks them to do." (Thanh, Interview extract).

"Learners can dance and sing the song. That's fun and entertaining. They like to learn more new words instead of sitting in one place." (Thy, Interview extract).

"I think songs used to start the lesson always make learners feel excited as they can feel at ease and move." (Nguyen, Interview extract).

\subsection{Enhancing Reading and Writing}

One teacher thought through practicing listening to the songs, young learners could develop reading and writing abilities. Phi said,

"When learners are asked to observe or look at an activity related to the song, they can write or read words from that song." (Phi, Interview extract).

\subsection{Improving Pronunciation}

Two teachers contended that songs could help improve or facilitate young learners' pronunciation of words. Nhi said,

"Songs help young learners pronounce the sounds or words set in songs more exactly by listening to songs." (Nhi, interview extract).

Lan emphasized that if young learners listened to songs many times, their pronunciation of new words could be improved thanks to singers' accents. Lan shared,

"Young learners will improve their pronunciation of words because video songs contain standard accents, which young learners listen to and repeat many times."
(Lan, interview extract).

\section{Discussion}

Findings from this study reveal that the participating teachers perceived songs as beneficial in teaching vocabulary to young learners. In particular, these teachers reported that songs were effective in young learners' vocabulary instruction with regard to amount of words, retention, increased attention, friendly environment, practice opportunities, and meaningful contexts. These positive aspects suggest that songs serve as a useful tool for promoting young learners' vocabulary, which aligns with findings of several studies[e.g., 4, 6, 14, 22]. These authors claim that songs are a valuable resource for teachers to promote lexical knowledge and improvements of young learners through their exposure and repeated occurrences or practices. The study provides insights into how teachers' perceptions can influence their decision-making in selecting songs and appropriate strategies in order to involve young learners in interactive, entertaining, and motivating learning process of vocabulary gains.

Analysis from the interview responses reveals themes that were congruent with teachers' perceptions about songs in vocabulary instruction from the findings from the questionnaire. Pronunciation practice of words reported as an improved part of young learners' English through songs confirms the connection between songs and language learning, as documented in the literature[50, 51]. These argue that listening to music and songs can enhance listening skills in a foreign language, one of the key features needed for language learning. From the linguistic perspective, songs provide learners a source of language to develop their listening abilities, including pronunciation coupled with grammar, syntax, and vocabulary development.

\section{Conclusions}

The findings from the study show that teachers had positive perceptions about using songs in instructing vocabulary to young learners. There are some important pedagogical implications for teachers and school administrators. First, teachers' perceptions about using songs in vocabulary instruction to young learners play an important role in young learners' vocabulary gains. Given the importance of perceived effects of songs, it is important for teachers to become more aware of their roles and responsibility for providing young learners with apposite contexts to learn and practice vocabulary through songs as a potentially resourceful means. Furthermore, teachers should find ways to select songs pertinent to the needs and interests of learners in order to enhance learners' vocabulary gains in their learning process. Moreover, teachers should be given opportunities to have professional 
development training particularly in using songs in different classroom contexts of vocabulary learning in order to meet the English proficiency levels of young learners. Schools or language center authorities should equip classrooms with facilities for teachers to make best use of songs and create a fun and motivating learning space or atmosphere for learners.

\section{REFERENCES}

[1] N. Schmitt, Vocabulary in language teaching. Cambridge: Cambridge University Press, 2000.

[2] N. Schmitt, Researching vocabulary: A vocabulary research manual. United Kingdom: Palgrave Mcmillan, 2010.

[3] I. S. P. Nation, Learning vocabulary in another language. Cambridge: Cambridge University Press, 2001.

[4] N. T. Millington, "Using songs effectively to teach English to young learners," Language Education in Asia, vol. 2, pp. 134-141, 2011.

[5] C. Shen, "Using English songs: An enjoyable and effective approach in ELT," English Language Teaching, vol. 2, pp. 88-94, 2009.

[6] N. Pavia, S. Webb, and F. Faez, "Incidental vocabulary through listening to songs," Studies in Second Language Acquisition, vol. 41, pp. 745-768, 2019.

[7] Ministry of Education and Training, "Teaching and learning foreign languages in the national education system from 2008 to 2020," ed. Hanoi: Vietnam, 2008.

[8] R. Adams and J. Newton, "TBLT in Asia: Constraints and opportunities," Asian Journal of English Language Teaching, vol. 19, pp. 1-17, 2009.

[9] T. N. Le and H. B. Nguyen, "Task-based language learning and student motivation in vocabulary acquisition," Language Education in Asia, vol. 3, pp. 106-120, 2012.

[10] J. C. Richards, P. B. Gallo, and W. A. Renandya, "Exploring teachers' beliefs and the processes of change," PAC Journal, 2001.

[11] G. M. Davis, "Songs in the young learner classroom: A critical review of evidence," ELT Journal, vol. 71, pp. 445-455, 2018.

[12] G. M. Davis and W. Fan, "English vocabulary acquisition through songs in Chinese kindergarten students," Chinese Journal of Applied Linguistics, vol. 39, pp. 59-71, 2016.

[13] D. Engh, "Why use music in English language learning? A survey of the literature," English Language Teaching, vol. 6, pp. 113-127, 2013.

[14] S. A. Albaladejo, Y. Coyle, and J. R. de Larios, "Songs, stories, and vocabulary acquisition in preschool learners of English as a foreign language," System, vol. 76, pp. 116-128, 2018.

[15] M. Ward, G. Grinstein, and D. Keim, Interactive data visualization: Foundations, techniques and applications (2nd Ed.). New York: A K Peters/ CRC Press, 2015.

[16] P. Eggen and D. Kauchak, Educational psychology: Windows on classrooms (5th Ed.). Upper Saddle River, NJ: Merrill Prentice Hall, 2001.

[17] L. M. Anderson and J. A. Stillman, "Student teaching's contribution to preservice teacher development: A review of research focused on the preparation of teachers for urban and high-needs contexts," Review of Educational Research, vol. 83, pp. 3-69, 2013.

[18] P. Sangster, C. Anderson, and P. O'Hara, "Perceived and actual levels of knowledge about language amongst primary and secondary student teachers: Do they know what they think they know?," Language Awareness, vol. 22, pp. 293-319, 2013.

[19] H. T. Tran, "EFL teachers' perceptions about vocabulary acquisition and instruction," $\mathrm{PhD}$, Alliant International University, San Diego, California, 2011.

[20] C. S. M. Lee, "Teachers' perceptions in developing robust vocabulary instruction," PhD, College of Education, Walden University, Minneapolis, Minnesota, USA, 2017.

[21] S. Gass, "Discussion: Incidental vocabulary learning," Studies in Second Language Acquisition, vol. 21, pp. 319-333, 1999.

[22] K. Ezzair, "English teachers' perceptions of vocabulary instruction in English language learners' classrooms," $\mathrm{PhD}$, College of Education, Walden University, Minneapolis, Minnesota, USA, 2019.

[23] P. Nation, What should every EFL teacher know. Tokyo, Japan: Compass Publishing, 2013.

[24] J. C. Richards and T. Rodgers, Approaches and methods in language teaching. Cambridge: Cambridge University Press, 2001.

[25] G. Ellis, "Young learners: Clarifying our terms," ELT Journal, vol. 68, pp. 75-78, 2014.

[26] S. Phillips, Young learners. Bristol, UK: Oxford University Press, 1993.

[27] L. Cameron, Teaching language to young learners. Cambridge: Cambridge University Press, 2001.

[28] P. McKay, Assessing young language learners. Cambridge: Cambridge University Press, 2006.

[29] J. K. Shin and J. A. Crandall, Teaching young learners English: From theory to practice. Boston, MA: National Geographic Learning, 2014.

[30] S. Thomson, "Title," unpublished|.

[31] L. Cameron, "Challenges for ELT from the expansion in teaching children," ELT Journal, vol. 57, pp. 105-112, 2003.

[32] D. Nunan, Teaching English to young learners. Anaheim, CA: Anaheim University Press, 2011.

[33] K. Q. T. Lieu and H. B. Nguyen, "Impact of pictures on young learners' speaking ability at a primary school in Tra Vinh province, Vietnam," The International Journal of Humanities and Social Studies, vol. 6, pp. 441-447, 2018.

[34] J. Newton, "Incidental vocabulary learning in classroom 
communicative tasks," Language Teaching Research, vol. 17, pp. 164-187, 2013.

[35] H. G. T. Nguyen and H. B. Nguyen, "Teachers' perceptions about vocabulary instruction through flashcards at English language centers in the Mekong Delta city,"i-manager's Journal on English Language Teaching, vol. 9, pp. 36-48, 2019.

[36] N. D. Džanić and A. Pejić, "The effect of using songs on young learners and their motivation for learning English," An Interdisciplinary Journal, vol. 1, pp. 40-54, 2016.

[37] D. Yuksel, "Using songs in teaching English to very young learners," MA, Institute of Graduate Studies and Research, Eastern Mediteranean University, North Cyprus, 2016.

[38] M. R. Trinick, "Sound and sight: The use of songs to promote language learning," National Association for Music Education, vol. 25, pp. 5-10, 2011.

[39] Y. Coyle and R. G. Gracia, "Using songs to enhance L2 vocabulary acquisition in preschool children," ELT Journal, vol. 68, pp. 276-285, 2014

[40] M. Chou, "Assessing English vocabulary and enhancing young English as a foreign language learners' motivation through games, songs, and stories," Education, vol. 42, pp. 284-297, 2014.

[41] A. A. Mamun, "Effectiveness of audio-visual aids in language teaching in tertiary level," MA, BRAC Institute of Languages, BRAC University, Dhaka, 2014.

[42] M. A. Facella, K. M. Rampinio, and E. K. Shea, "Effective teaching strategies for English language learners," Bilingual Research Journal, vol. 29, pp. 209-221, 2005.

[43] M. Evans and L. Fisher, "Emergent communities of practice: Secondary schools' interaction with primary school foreign language teaching and learning," The Language Learning Journal, vol. 40, pp. 157-173, 2012.

[44] L. Jin and M. Cortazzi, "Changing practices in Chinese cultures of learning," Language, Culture and Curriculum, vol. 19, pp. 5-20, 2006.

[45] N. Konstantakis and T. Alexiou, "Vocabulary in Greek young learners' English as a foreign language course books," The Language Learning Journal, vol. 40, pp. 35-45, 2012.

[46] K. Hashimoto, "Compulsory 'foreign language activities' in Japanese primary schools," Current Issues in Language Planning, vol. 12, pp. 167-184, 2011.

[47] R. Setia, R. A. Rahim, G. K. S. Nair, A. F. b. M. Adam, N. Husin, E. Sabapathy, et al., "English songs as means of aiding students' proficiency development," Asian Social Science, vol. 8, pp. 270-274, 2012.

[48] H. T. M. Nguyen, "Primary English language education policy in Vietnam: Insights from implementation," Current Issues in Language Planning, vol. 12, pp. 225-249, 2011.

[49] C. Case, "The pedagogical value of games and songs," T. a. H. S. Faculty of Education, Ed., ed. University of Vic-Central University of Catalonia, Spain, 2014.

[50] M. C. Fonseca-Mora, C. Toscano-Fuentes, and K. Wermke, "Melodies that help: The relation between language aptitude and musical intelligence,"Anglistik: International Journal of English Studies, vol. 22, pp. 101-118, 2011.
[51] M. Diakou, "Using songs to enhance language learning and skills in the Cypriot primary EFL classroom," EdD Open Research Repository, The Open University, UK, 2013. 